\title{
Synthesis and structural studies of some selenoureas and their metal complexes
}

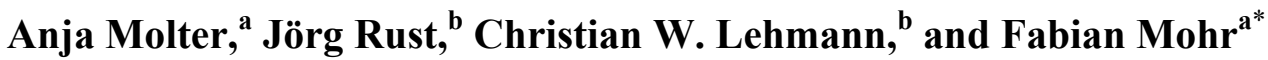 \\ ${ }^{a}$ Fachbereich C - Anorganische Chemie, Bergische Universität Wuppertal, \\ 42119 Wuppertal, Germany \\ ${ }^{b}$ Max-Planck Institut für Kohlenforschung, 45470 Mülheim an der Ruhr, Germany \\ E-mail:fmohr@uni-wuppertal.de
}

\section{Unserem Freund Professor Heinz Heimgartner in Anerkennung seiner schönen Arbeiten auf dem Gebiet der Selenchemie zum 70. Geburtstag gewidmet}

\begin{abstract}
The selenoureas PhC(O)NHC(Se)NPhMe, 4- $\mathrm{MeC}_{6} \mathrm{H}_{4} \mathrm{C}(\mathrm{O}) \mathrm{NHC}(\mathrm{Se}) \mathrm{NPhMe}$ and 4- $\mathrm{MeC}_{6} \mathrm{H}_{4} \mathrm{C}(\mathrm{O})$ $\mathrm{NHC}(\mathrm{Se}) \mathrm{NEt}_{2}$ were prepared and characterized by spectroscopic methods and single crystal X-ray diffraction. 4- $\mathrm{MeC}_{6} \mathrm{H}_{4} \mathrm{C}(\mathrm{O}) \mathrm{NHC}(\mathrm{Se}) \mathrm{NEt}_{2}$ was reacted with some $\mathrm{Pt}(\mathrm{II}), \mathrm{Pd}(\mathrm{II})$ and $\mathrm{Ru}(\mathrm{II})$ precursors to give heteroleptic, cationic metal complexes which were characterized by NMR spectroscopy, electrospray mass spectrometry and, in the case of the $\operatorname{Pd}(\mathrm{II})$ complex $[\operatorname{Pd}\{4$ $\left.\mathrm{MeC}_{6} \mathrm{H}_{4} \mathrm{C}(\mathrm{O}) \mathrm{NC}(\mathrm{Se}) \mathrm{NEt}_{2}\right\}\left({ }^{t} \mathrm{Bu}_{2}\right.$ bipy $\left.)\right] \mathrm{PF}_{6}$ by X-ray diffraction.
\end{abstract}

Keywords: Selenourea, NMR spectroscopy, X-ray crystal structure, metal complexes

\section{Introduction}

Selenoureas of the type $\mathrm{RC}(\mathrm{O}) \mathrm{NHC}(\mathrm{Se}) \mathrm{NR}^{\prime} \mathrm{R}^{\text {" }}$ derived from the reaction of an acid chloride with $\mathrm{KSeCN}$ and subsequent addition of an amine have been known since 1937. ${ }^{1}$ The rather complex chemistry involved in the formation of the intermediate acylisoselenocyanates $\mathrm{RC}(\mathrm{O}) \mathrm{NCSe}$ has been studied by various groups, among them that of Heimgartner. ${ }^{2-4}$ While the acylisoselenocyanates are important intermediates in organoselenium chemistry, ${ }^{5,6}$ the selenoureas themselves have been extensively studied by the inorganic and analytical communities. Selenoureas react with metal salts to form chelate complexes in which the deprotonated selenourea acts as a monoanionic O,Se-donor forming a six-membered metallacycle (Figure 1). 


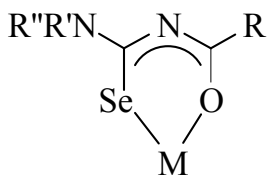

Figure 1. Schematic representation of a selenoureato metal chelate complex.

Depending on the valency of the metal, one, two or three selenoureato ligands can be accommodated.

Metal complexes of this type, in particular the bis(selenoureato) derivatives have been extensively studied and have found application in analytical chemistry for chromatographic metal separation ${ }^{7,8}$ and also for spectrophotometric determination of metals. ${ }^{9}$ More recently, main group metal selenoureato complexes have been explored as single source precursors for the preparation of metal selenide nanomaterials. ${ }^{10,11}$ While such homoleptic selenoureato complexes have been studied in great detail, heteroleptic derivatives are virtually unknown. We previously reported the first examples of heteroleptic selenoureato palladium complexes derived from a cyclometalled palladium(II) precursor. ${ }^{12}$ We have now extended this work to encompass other selenoureas and present the results of this study here.

\section{Results and Discussion}

The selenoureas $\mathrm{PhC}(\mathrm{O}) \mathrm{NHC}(\mathrm{Se}) \mathrm{NPhMe} \quad \mathbf{1}, \quad 4-\mathrm{MeC}_{6} \mathrm{H}_{4} \mathrm{C}(\mathrm{O}) \mathrm{NHC}(\mathrm{Se}) \mathrm{NPhMe} \quad \boldsymbol{2}$ and $4-\mathrm{MeC}_{6} \mathrm{H}_{4} \mathrm{C}(\mathrm{O}) \mathrm{NHC}(\mathrm{Se}) \mathrm{NEt}_{2} 3$ were prepared in a one pot procedure from the reaction of the appropriate acid chloride with $\mathrm{KSeCN}$ and subsequent addition of $\mathrm{N}$-methyl aniline or $\mathrm{Et}_{2} \mathrm{NH}$ (Scheme 1).<smiles>[R]c1ccc(C(=O)Cl)cc1</smiles>
(a) $\mathrm{KSeCN}$
(b) R'R"NH<smiles>[R]c1ccc(C(=O)NC(=[Se])N([R])[Z])cc1</smiles>

1: $\mathrm{R}=\mathrm{H}, \mathrm{R}^{\prime}=\mathrm{Ph}, \mathrm{R}^{\prime \prime}=\mathrm{Me}$

2: $\mathrm{R}=\mathrm{Me}, \mathrm{R}^{\prime}=\mathrm{Ph}, \mathrm{R}^{\prime \prime}=\mathrm{Me}$

3: $\mathrm{R}=\mathrm{Me}, \mathrm{R}^{\prime}=\mathrm{R}^{\prime \prime}=\mathrm{Et}$

Scheme 1. Synthesis of selenoureas 1-3.

The compounds were characterized by ${ }^{1} \mathrm{H}$ NMR spectroscopy and, in the case of $\mathbf{1}$ and $\mathbf{2}$, also by single crystal X-ray diffraction. The molecular structures of compounds $\mathbf{1}$ and $\mathbf{2}$ are shown in Figures 2-3, respectively; important bond distances and angles are collected in Table 1. 


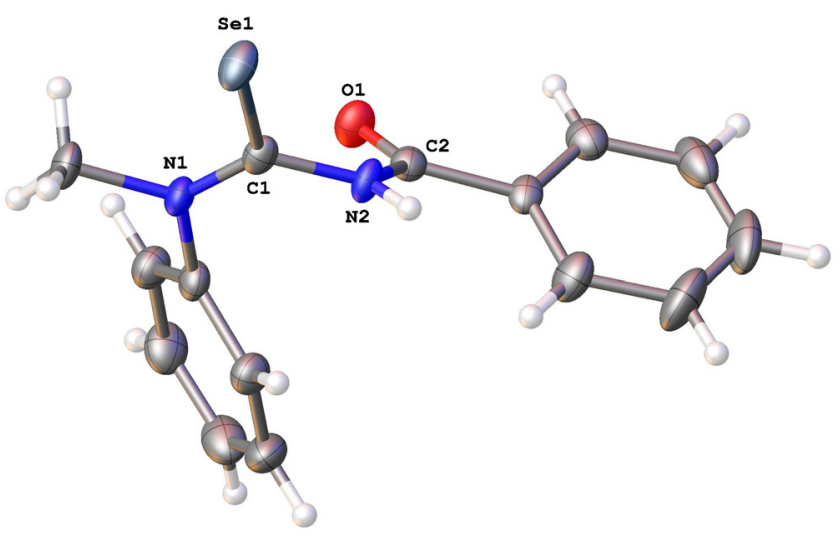

Figure 2. Molecular structure of 1. Ellipsoids show 50\% probability levels.

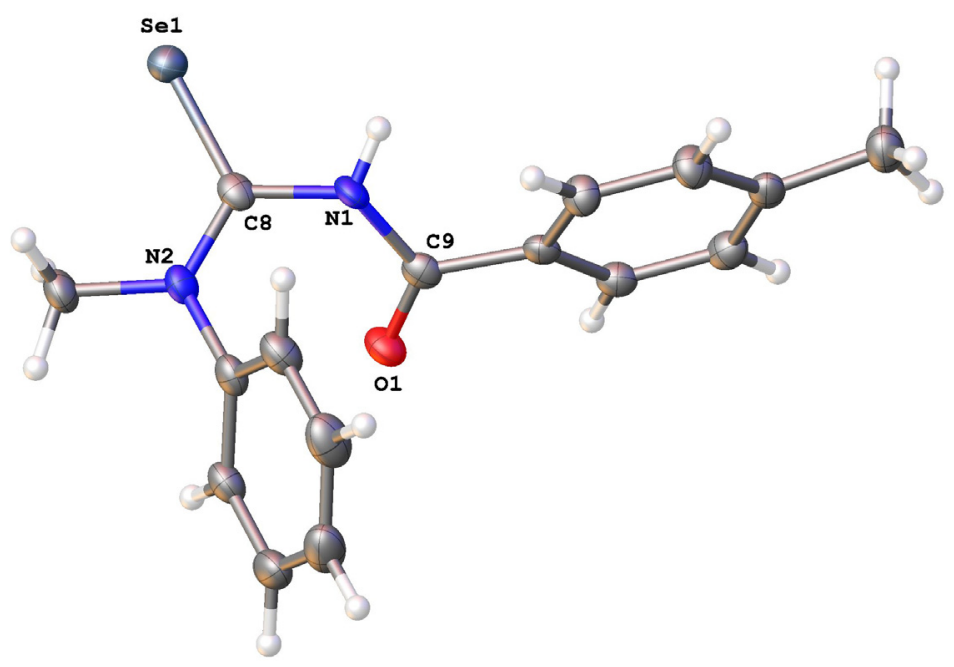

Figure 3. Molecular structure of 2. Ellipsoids show 50\% probability levels.

Table 1. Important bond distances $(\AA)$ and bond angles $\left(^{\circ}\right)$ in selenoureas $\mathbf{1}$ and $\mathbf{2}$

\begin{tabular}{lccc}
\hline \multicolumn{2}{c}{ Compound 1 } & \multicolumn{2}{c}{ Compound 2 } \\
\hline Se1-C1 1.834(2) & N1-C1-Se1 123.26(14) & Se1-C8 1.8291(19) & N2-C8-Se1 123.49(15) \\
O1-C2 1.220(2) & C1-N2-C2 123.33(17) & O1-C9 1.219(2) & C8-N1-C9 124.21(16) \\
C1-N2 1.396(2) & O1-C2-N2 122.41(8) & C8-N1 1.394(2) & O1-C9-N1 121.71(19) \\
C2-N2 1.384(3) & N1-C1-N2 118.12(17) & C9-N1 1.394(2) & N1-C8-N2 117.26(16) \\
C1-N1 1.324(3) & & C8-N2 1.332(2) & \\
\hline
\end{tabular}

The two structures show very similar bond lengths and angles and the overall geometry i.e. the rotation of the $\mathrm{C}=\mathrm{Se}$ and $\mathrm{C}=\mathrm{O}$ units with respect to each other $\left(c a .126^{\circ}\right)$ is also very similar. 
The $\mathrm{C}=\mathrm{Se} / \mathrm{O}$ as well as the $\mathrm{C}-\mathrm{N}$ distances are within the expected values for double and single bonds, respectively.

Selenourea 3 reacted with the palladium and platinum precursors $c i s-\left[\mathrm{MCl}_{2}(\mathrm{~L}-\mathrm{L})\right][\mathrm{M}=\mathrm{Pt}$, $\mathrm{Pd} ; \mathrm{L}-\mathrm{L}={ }^{t} \mathrm{Bu}_{2}$ bipy, $\left.\left(\mathrm{PPh}_{3}\right)_{2}\right]$ in the presence of base to give the cationic complexes $\left[\mathrm{M}\left\{4-\mathrm{MeC}_{6} \mathrm{H}_{4} \mathrm{C}(\mathrm{O}) \mathrm{NC}(\mathrm{Se}) \mathrm{NEt}_{2}\right\}(\mathrm{L}-\mathrm{L})\right]^{+}$4-6, which were isolated as their $\mathrm{PF}_{6}^{-}$or $\mathrm{BPh}_{4}{ }^{-}$salts (Scheme 2). Similarly, the reaction of 3 with the ruthenium precursor $\left[\mathrm{RuCl}_{2}(p \text {-cym) }]_{2}\right.$ in the presence of $\mathrm{Ph}_{3} \mathrm{P}$ and base gave the cationic ruthenium complex $\left[\mathrm{Ru}\left\{4-\mathrm{MeC}_{6} \mathrm{H}_{4} \mathrm{C}(\mathrm{O}) \mathrm{N}-\right.\right.$ $\left.\mathrm{C}(\mathrm{Se}) \mathrm{NEt}_{2}\right\}\left(\mathrm{PPh}_{3}\right)(p$-cym $\left.)\right] 7$ as shown in Scheme 2.<smiles>CCNC(=[Se])NC(=O)c1ccc(C)cc1</smiles>

3
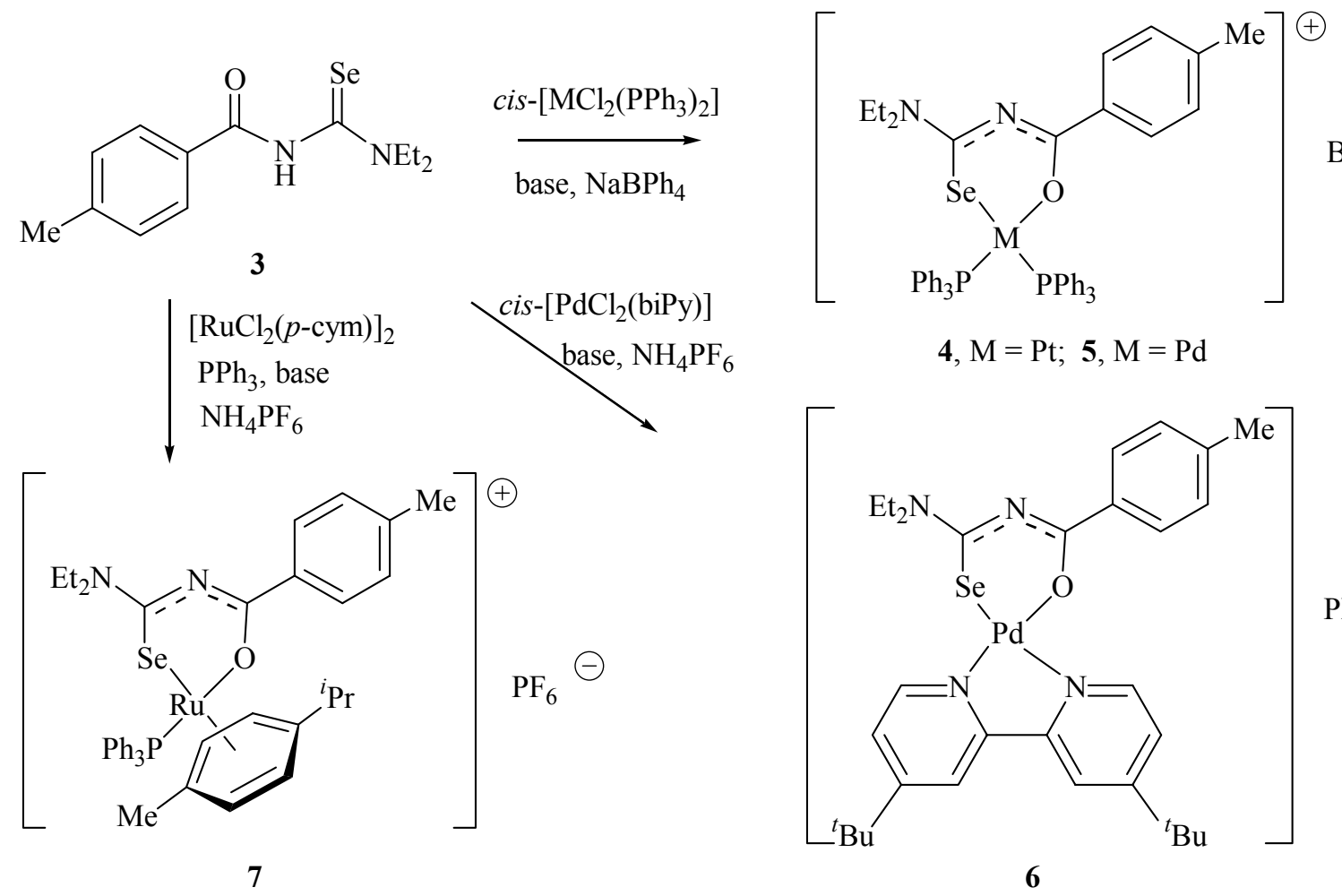

$\mathrm{BPh}_{4} \odot$

4, $\mathrm{M}=\mathrm{Pt} ; \mathbf{5}, \mathrm{M}=\mathrm{Pd}$

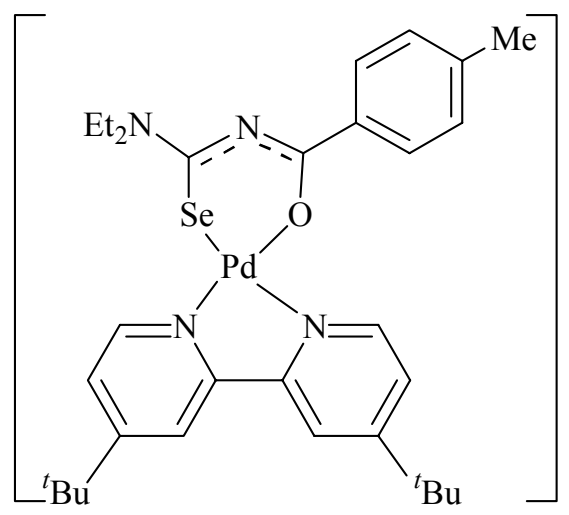

$\mathrm{PF}_{6} \odot$

Scheme 2. Preparation of $\mathrm{Pt}, \mathrm{Pd}$ and $\mathrm{Ru}$ complexes with thiourea 3.

The cationic complexes 4-7 were characterized by ${ }^{1} \mathrm{H}$ and ${ }^{31} \mathrm{P}\left\{{ }^{1} \mathrm{H}\right\}$ NMR spectroscopy and electrospray mass spectrometry as well as elemental analysis. The compounds appear indefinitely stable in the solid state, but, in solution, decomposition occurs over a period of $c a$. 12-18 h. The poor solubility of the complexes combined with the low sensitivity of the ${ }^{77}$ Se and ${ }^{13} \mathrm{C}$ nuclei did unfortunately not allow us to obtain NMR spectra of these two nuclei. We were however able to obtain X-ray quality crystals of complex 6 (see below). Complexes 4-7 show strong parent ions due to the cations in the electrospray mass spectra; in some cases an additional signal due to loss of a $\mathrm{Ph}_{3} \mathrm{P}$ ligand is also seen. The observed isotopic distribution patterns exactly match the computed patterns. The ${ }^{31} \mathrm{P}\left\{{ }^{1} \mathrm{H}\right\}$ NMR spectra of the phosphine complexes 4 and 5, show two doublet resonances due to the presence of nonequivalent phosphorus atoms. In 
addition, Pt satellites with P-Pt coupling constants of ca. $3000 \mathrm{~Hz}$, typical for a cis geometry about the platinum, are observed in complex 4. In the ${ }^{1} \mathrm{H}$ NMR spectra of all four complexes, the signal due to the NH proton is absent, confirming that deprotonation of the selenourea has occurred. Furthermore, the doubling of all the proton signals of the ${ }^{t} \mathrm{Bu}_{2}$ bipy moiety suggests an unsymmetrical environment about the metal, which is consistent with the presence of a chelating selenoureato ligand. The proposed structure was confirmed by an X-ray diffraction study of complex 6, shown in Figure 4.

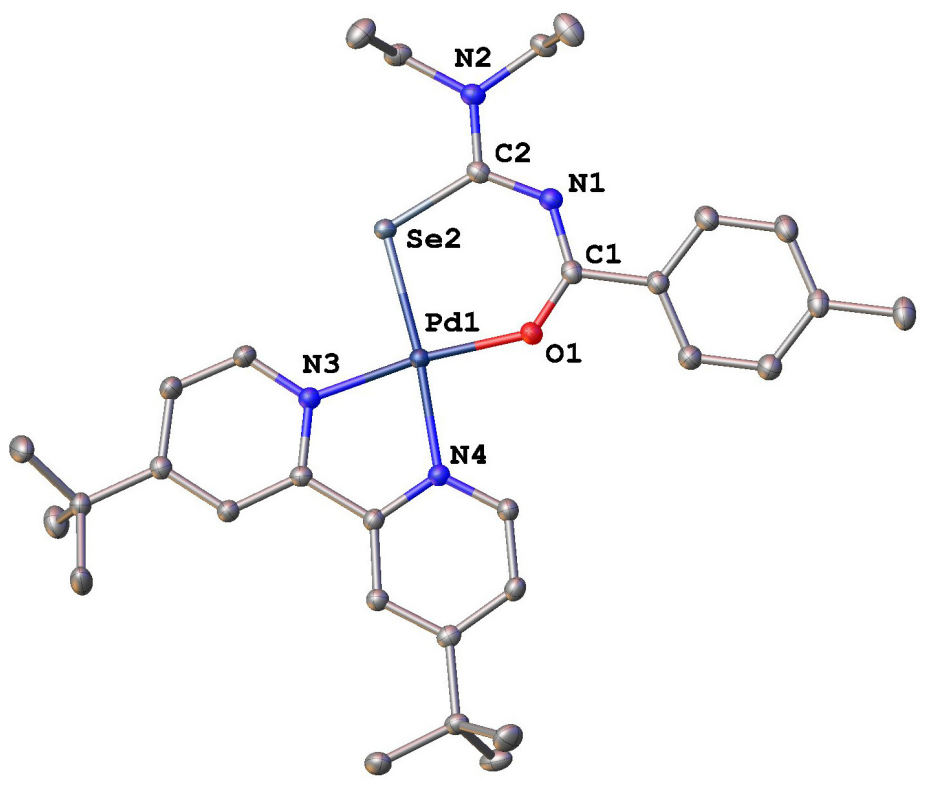

Figure 4. Molecular structure of the cation of complex 6. Ellipsoids show $50 \%$ probability levels. Hydrogen atoms as well as the $\mathrm{PF}_{6}{ }^{-}$anion have been omitted for clarity.

The cation consists of a palladium atom coordinated by the two nitrogen atoms of the ${ }^{t} \mathrm{Bu}_{2}$ bipy as well as the oxygen and selenium atoms of the deprotonated selenoureato ligand in a square planar fashion. Overall, the structure is similar to the previously reported related sulfur analogue. ${ }^{13}$ The bond distances $(\mathrm{C}-\mathrm{Se} / \mathrm{O}$ and $\mathrm{C}-\mathrm{N})$ of the selenoureato ligand are considerably different than those observed in the selenoureas themselves: The $\mathrm{C}-\mathrm{Se}$ and $\mathrm{C}-\mathrm{O}$ bond lengths increase upon coordination [C2-Se2 1.8895(18) $\AA, \mathrm{C} 1-\mathrm{O} 1$ 1.281(2) $\AA$ ], while the C-N bond distances decrease [C1-N1 1.325(2) $\AA$, C2-N1 1.340(2) $\AA$ ], consistent with the change of bond order due to delocalization which occurs upon deprotonation. While the five-membered Pd-N-C$\mathrm{C}-\mathrm{N}$ ring is planar, the $\mathrm{O}$ and $\mathrm{Se}$ atoms of the six-membered $\mathrm{Pd}-\mathrm{O}-\mathrm{C}-\mathrm{N}-\mathrm{C}-\mathrm{Se}$ ring lie slightly above and below the mean plane, respectively.

The ruthenium complex 7 is chiral at the metal centre, which results in the doubling of all the proton resonances in its ${ }^{1} \mathrm{H}$ NMR spectrum. Such behavior is typically observed in NMR spectra of ruthenium complexes which are chiral at the metal. ${ }^{14}$ Unfortunately, we were unable to obtain 
X-ray quality crystals of this compound; nevertheless, the spectral data are fully consistent with the proposed structure.

In summary, we have prepared and characterized some new selenourea derivatives and have shown that deprotonation in the presence of $\mathrm{Pt}(\mathrm{II}), \mathrm{Pd}(\mathrm{II})$ and $\mathrm{Ru}(\mathrm{II})$ precursors leads to the formation of cationic, heteroleptic selenoureato complexes.

\section{Experimental Section}

General. ${ }^{1} \mathrm{H}$ and ${ }^{31} \mathrm{P}\left\{{ }^{1} \mathrm{H}\right\}$ NMR spectra were recorded on a $400 \mathrm{MHz}$ Bruker Avance spectrometer. Chemical shifts are quoted relative to external $\mathrm{SiMe}_{4}\left({ }^{1} \mathrm{H}\right)$ and $85 \% \mathrm{H}_{3} \mathrm{PO}_{4}\left({ }^{31} \mathrm{P}\right)$. Elemental analyses were performed by staff of the microanalytical laboratory of the University of Wuppertal. Positive ion electrospray mass spectra were run as $\mathrm{MeCN}$ solutions on a Bruker Daltonics instrument. All reactions were carried out under aerobic conditions in standard glassware. KSeCN was prepared from Se metal and $\mathrm{KCN}$ as described elsewhere. ${ }^{15}$ The metal precursors cis-[ $\left[\mathrm{MCl}_{2}\left(\mathrm{PPh}_{3}\right)_{2}\right](\mathrm{M}=\mathrm{Pt}, \mathrm{Pd})$, cis-[ $\left.\mathrm{PdCl}_{2}\left({ }^{t} \mathrm{Bu}_{2} \mathrm{bipy}\right)_{2}\right]$ and $\left[\mathrm{RuCl}_{2}(p \text {-cym })\right]_{2}$ were prepared as described in the literature. ${ }^{16,17}$ All other chemicals and solvents (HPLC grade) were sourced commercially and used as received. Full details of the crystallographic studies are provided in the supplementary material. The structural data have been deposited at the Cambridge Crystallographic Data Centre with the deposition codes CCDC 791347 - 791349.

\section{Preparation of the selenoureas (1, 2 and 3)}

To a solution of $\mathrm{KSeCN}(1.53 \mathrm{~g}, 0.01 \mathrm{mmol})$ in acetone $(25 \mathrm{~mL})$ was added the appropriate acid chloride $(0.01 \mathrm{mmol})$. After stirring for $c a .30 \mathrm{~min}$., the amine $(0.01 \mathrm{mmol})$ was added and the resulting mixture was stirred a further $30 \mathrm{~min}$. The reaction mixture was poured into $0.1 \mathrm{M} \mathrm{HCl}$ (ca. $200 \mathrm{~mL}$ ) and the resulting orange precipitate was filtered, washed with water and dried. The pure selenoureas were obtained from recrystallisation of the crude material with EtOH.

$\boldsymbol{N}$-Benzoyl- $\boldsymbol{N}$ '-methyl- $\boldsymbol{N}$ '-phenylselenourea (1). Orange crystals, 55\% yield, ${ }^{1} \mathrm{H}$ NMR (400 $\mathrm{MHz}, \mathrm{CDCl}_{3}$ ), $\delta_{\mathrm{H}} 3.88$ (3H, br. s, NMe), 7.17-7.64 (10H, m, Arom), 8.66 (1H, br. s, NH). Anal. Calcd. for $\mathrm{C}_{15} \mathrm{H}_{14} \mathrm{~N}_{2} \mathrm{OSe}$ (317.24): C, 56.79; H, 4.45; N, 8.83\%, Found: C, 56.67; H, 4.33; N, $9.02 \%$. X-ray quality crystals were picked from the bulk sample.

$\boldsymbol{N}$-(4-Methylbenzoyl)- $\boldsymbol{N}^{\prime}$-methyl- $\boldsymbol{N}^{\prime}$-phenylselenourea (2). Yellow crystals, $64 \%$ yield, ${ }^{1} \mathrm{H}$ NMR (400 MHz, CDCl 3 ), $\delta_{\mathrm{H}} 2.35$ (3H, s, Me), 3.88 (3H, br. s, NMe), 7.07-7.58 (9H, m, Arom), 8.62 (1H, br. s, $\mathrm{NH}$ ). Anal. Calcd. for $\mathrm{C}_{16} \mathrm{H}_{16} \mathrm{~N}_{2} \mathrm{OSe}$ (331.27): C, 58.01; H, 4.87; N, 8.46\%, Found: C, 58.11; H, 5.03; N, 8.44\%. \%. X-ray quality crystals were picked from the bulk sample. $\boldsymbol{N}$-(4-Methylbenzoyl)- $\boldsymbol{N}^{\prime}, \boldsymbol{N}^{\prime}$-diethylselenourea (3). Orange crystals, $69 \%$ yield. ${ }^{1} \mathrm{H}$ NMR (400 $\left.\mathrm{MHz}, \mathrm{CDCl}_{3}\right), \delta_{\mathrm{H}} 1.31\left(3 \mathrm{H}, \mathrm{t},{ }^{3} J_{\mathrm{HH}}=7.1 \mathrm{~Hz}, \mathrm{CH}_{3}\right), 1.41\left(3 \mathrm{H}, \mathrm{t},{ }^{3} J_{\mathrm{HH}}=7.1 \mathrm{~Hz}, \mathrm{CH}_{3}\right), 2.42(3 \mathrm{H}, \mathrm{s}$, $\mathrm{Me}), 3.62\left(2 \mathrm{H}, \mathrm{q},{ }^{3} J_{\mathrm{HH}}=7.1 \mathrm{~Hz}, \mathrm{NCH}_{2}\right), 4.15\left(2 \mathrm{H}, \mathrm{q},{ }^{3} J_{\mathrm{HH}}=7.1 \mathrm{~Hz}, \mathrm{NCH}_{2}\right), 7.27\left(2 \mathrm{H}, \mathrm{d},{ }^{3} J_{\mathrm{HH}}=\right.$ $8.1 \mathrm{~Hz}$, Arom), $7.74\left(2 \mathrm{H}, \mathrm{d},{ }^{3} J_{\mathrm{HH}}=8.1 \mathrm{~Hz}\right.$, Arom), $8.43(1 \mathrm{H}$, br. s, NH). Anal. Calcd. for $\mathrm{C}_{13} \mathrm{H}_{18} \mathrm{~N}_{2} \mathrm{OSe}$ (297.25): C, 52.53; H, 6.10; N, 9.42\%, Found: C, 52.78; H, 6.07; N, 9.43\%. 


\section{Preparation of the selenoureato metal complexes (4-7)}

A mixture containing the metal precursor (see General paragraph), $3, \mathrm{NH}_{4} \mathrm{PF}_{6}$ or $\mathrm{NaBPh}_{4}(\mathrm{slight}$ excess) and $\mathrm{Ph}_{3} \mathrm{P}$ (for complex 7) in $\mathrm{MeOH}(10 \mathrm{~mL})$ was treated with $\mathrm{Et}_{3} \mathrm{~N}(1 \mathrm{~mL})$ and heated to reflux for 10-15 min. Water was added to the cooled solution, which caused precipitation of the products. These were isolated by filtration, washed with water and $\mathrm{Et}_{2} \mathrm{O}$ and were subsequently dried in air.

Complex (4). Dark yellow solid, 93\% yield. ${ }^{31} \mathrm{P}\left\{{ }^{1} \mathrm{H}\right\} \mathrm{NMR}\left(162 \mathrm{MHz}, \mathrm{CDCl}_{3}\right), \delta_{\mathrm{P}} 21.60\left(\mathrm{~d},{ }^{2} J_{\mathrm{PP}}\right.$ $\left.=22.9 \mathrm{~Hz},{ }^{1} J_{\mathrm{PPt}}=3086 \mathrm{~Hz}\right), 8.87\left(\mathrm{~d},{ }^{2} J_{\mathrm{PP}}=22.9 \mathrm{~Hz},{ }^{1} J_{\mathrm{PPt}}=3078 \mathrm{~Hz}\right) .{ }^{1} \mathrm{H} \mathrm{NMR}(400 \mathrm{MHz}$, $\left.\mathrm{CDCl}_{3}\right), \delta_{\mathrm{H}} 1.08\left(3 \mathrm{H}, \mathrm{t},{ }^{3} J_{\mathrm{HH}}=6.6 \mathrm{~Hz}, \mathrm{CH}_{3}\right), 1.22\left(3 \mathrm{H}, \mathrm{m}, \mathrm{CH}_{3}\right), 2.22(3 \mathrm{H}, \mathrm{s}, \mathrm{Me}), 3.48(2 \mathrm{H}, \mathrm{m}$, $\left.\mathrm{NCH}_{2}\right), 3.76\left(2 \mathrm{H}, \mathrm{m}, \mathrm{NCH}_{2}\right), 6.77(2 \mathrm{H}, \mathrm{m}$, Arom $), 6.87\left(4 \mathrm{H}, \mathrm{m}, \mathrm{BPh}_{4}\right), 6.97-7.61(48 \mathrm{H}, \mathrm{m}$, Arom, $\left.\mathrm{BPh}_{4}, \mathrm{PPh}_{3}\right)$. ES MS $(\mathrm{m} / z)$ : $1016.1989[M]^{+}$. Anal. Calcd. for $\mathrm{C}_{73} \mathrm{H}_{69} \mathrm{BN}_{2} \mathrm{OP}_{2} \mathrm{PtSe}$ (1337.40): C, 65.57; H, 5.20; N, 2.10\%, Found: C, 65.72; H, 5.49; N, 2.03\%.

Complex (5). Pale orange solid, 63\% yield. ${ }^{31} \mathrm{P}\left\{{ }^{1} \mathrm{H}\right\} \mathrm{NMR}\left(162 \mathrm{MHz}, \mathrm{CDCl}_{3}\right), \delta_{\mathrm{P}} 36.86\left(\mathrm{~d},{ }^{2} J_{\mathrm{PP}}=\right.$ $28.3 \mathrm{~Hz}), 23.73\left(\mathrm{~d},{ }^{2} J_{\mathrm{PP}}=28.3 \mathrm{~Hz}\right) .{ }^{1} \mathrm{H} \mathrm{NMR}\left(400 \mathrm{MHz}, \mathrm{CDCl}_{3}\right), \delta_{\mathrm{H}} 1.09\left(3 \mathrm{H}, \mathrm{t},{ }^{3} J_{\mathrm{HH}}=7.1 \mathrm{~Hz}\right.$, $\left.\mathrm{CH}_{3}\right), 1.23\left(3 \mathrm{H}, \mathrm{t},{ }^{3} J_{\mathrm{HH}}=7.1 \mathrm{~Hz}, \mathrm{CH}_{3}\right), 2.23(3 \mathrm{H}, \mathrm{s}, \mathrm{Me}), 3.53\left(2 \mathrm{H}, \mathrm{q},{ }^{3} J_{\mathrm{HH}}=7.1 \mathrm{~Hz}, \mathrm{NCH}_{2}\right)$, $3.77\left(2 \mathrm{H}, \mathrm{q},{ }^{3} J_{\mathrm{HH}}=7.1 \mathrm{~Hz}, \mathrm{NCH}_{2}\right), 6.77\left(2 \mathrm{H}, \mathrm{d},{ }^{3} J_{\mathrm{HH}}=8.1 \mathrm{~Hz}\right.$, Arom $), 6.85\left(4 \mathrm{H}, \mathrm{t}^{3} J_{\mathrm{HH}}=7.1 \mathrm{~Hz}\right.$, $\left.\mathrm{BPh}_{4}\right)$, 6.99-7.57 (48H, m, Arom, $\left.\mathrm{BPh}_{4}, \mathrm{PPh}_{3}\right)$. ES MS $(\mathrm{m} / \mathrm{z}): 927.1381[M]^{+}, 665.0459[M-$ $\left.P P h_{3}\right]^{+}$. Anal. Calcd. for $\mathrm{C}_{73} \mathrm{H}_{69} \mathrm{BN}_{2} \mathrm{OP}_{2} \mathrm{PdSe}$ (1248.48): C, 70.23; H, 5.57; N, 2.24\%, Found: C, 70.08; H, 5.38; N, 2.31\%.

Complex (6). Orange solid, 70\% yield. ${ }^{31} \mathrm{P}\left\{{ }^{1} \mathrm{H}\right\} \mathrm{NMR}\left(162 \mathrm{MHz}\right.$, acetone- $\left.\mathrm{d}_{6}\right), \delta_{\mathrm{P}}-142.96$ (sept, $\left.{ }^{1} J_{\mathrm{PF}}=713 \mathrm{~Hz}, \mathrm{PF}_{6}\right) .{ }^{1} \mathrm{H} \mathrm{NMR}\left(400 \mathrm{MHz}\right.$, acetone-d 6 ), $\delta_{\mathrm{H}} 1.37\left(3 \mathrm{H}, \mathrm{t},{ }^{3} J_{\mathrm{HH}}=7.1 \mathrm{~Hz}, \mathrm{CH}_{3}\right), 1.46$ $\left(13 \mathrm{H}, \mathrm{m},{ }^{t} \mathrm{Bu}, \mathrm{CH}_{3}\right), 1.51\left(9 \mathrm{H}, \mathrm{s},{ }^{t} \mathrm{Bu}\right), 2.43(3 \mathrm{H}, \mathrm{s}, \mathrm{Me}), 4.01-4.12\left(4 \mathrm{H}, \mathrm{m}, \mathrm{NCH}_{2}\right), 7.34(2 \mathrm{H}, \mathrm{d}$, ${ }^{3} J_{\mathrm{HH}}=8.6 \mathrm{~Hz}$, Arom $), 7.83\left(1 \mathrm{H}, \mathrm{dd},{ }^{3} J_{\mathrm{HH}}=6.1 \mathrm{~Hz},{ }^{4} J_{\mathrm{HH}}=2.0 \mathrm{~Hz}\right.$, bipy $), 8.10\left(1 \mathrm{H}, \mathrm{dd},{ }^{3} J_{\mathrm{HH}}=6.1\right.$ $\mathrm{Hz},{ }^{4} J_{\mathrm{HH}}=2.0 \mathrm{~Hz}$, bipy), $8.14\left(2 \mathrm{H}, \mathrm{d},{ }^{3} J_{\mathrm{HH}}=8.6 \mathrm{~Hz}\right.$, Arom $), 8.43\left(1 \mathrm{H}, \mathrm{d},{ }^{3} J_{\mathrm{HH}}=6.1 \mathrm{~Hz}\right.$, bipy $)$, $8.71\left(1 \mathrm{H}, \mathrm{d},{ }^{3} J_{\mathrm{HH}}=2.0 \mathrm{~Hz}\right.$, bipy), $8.75\left(1 \mathrm{H}, \mathrm{d},{ }^{3} J_{\mathrm{HH}}=2.0 \mathrm{~Hz}\right.$, bipy $), 8.92\left(1 \mathrm{H}, \mathrm{d},{ }^{3} J_{\mathrm{HH}}=6.1 \mathrm{~Hz}\right.$, bipy). ES MS (m/z): $671.1492[M]^{+}$. Anal. Calcd. for $\mathrm{C}_{31} \mathrm{H}_{43} \mathrm{~F}_{6} \mathrm{~N}_{4} \mathrm{OPPdSe}$ (818.04): C, 45.51; $\mathrm{H}$, 5.30; N, 6.85\%, Found: C, 45.29; H, 5.33; N, 7.01\%. \%. X-ray quality crystals were obtained by slow diffusion of $\mathrm{Et}_{2} \mathrm{O}$ into an acetone solution of the complex.

Complex (7). Yellow solid, 76\% yield. ${ }^{31} \mathrm{P}\left\{{ }^{1} \mathrm{H}\right\} \mathrm{NMR}\left(162 \mathrm{MHz}, \mathrm{CDCl}_{3}\right), \delta_{\mathrm{P}} 39.43$ (s, P-Ru), $142.96\left(\mathrm{sept},{ }^{1} J_{\mathrm{PF}}=713 \mathrm{~Hz}, \mathrm{PF}_{6}\right) .{ }^{1} \mathrm{H} \mathrm{NMR}\left(400 \mathrm{MHz}, \mathrm{CDCl}_{3}\right), \delta_{\mathrm{H}} 1.10\left(3 \mathrm{H}, \mathrm{d},{ }^{3} J_{\mathrm{HH}}=7.1 \mathrm{~Hz}\right.$, $\mathrm{MeCH}), 1.18\left(3 \mathrm{H}, \mathrm{d},{ }^{3} J_{\mathrm{HH}}=7.1 \mathrm{~Hz}, \mathrm{MeCH}\right), 1.28\left(3 \mathrm{H}, \mathrm{t},{ }^{3} J_{\mathrm{HH}}=7.1 \mathrm{~Hz}, \mathrm{CH}_{3}\right), 1.36\left(3 \mathrm{H}, \mathrm{t},{ }^{3} J_{\mathrm{HH}}=\right.$ $\left.7.1 \mathrm{~Hz}, \mathrm{CH}_{3}\right), 1.96\left(3 \mathrm{H}, \mathrm{s}, \mathrm{Me} p\right.$-cym), 2.34 (3H, s, Me Arom), $2.50\left(1 \mathrm{H}\right.$, sept, ${ }^{3} J_{\mathrm{HH}}=7.1 \mathrm{~Hz}$, $\mathrm{MeCH}), 3.65-3.68\left(1 \mathrm{H}, \mathrm{m}, \mathrm{NCH}_{2}\right), 3.81-3.99\left(2 \mathrm{H}, \mathrm{m}, \mathrm{NCH}_{2}\right), 4.25-4.36\left(1 \mathrm{H}, \mathrm{m}, \mathrm{NCH}_{2}\right), 5.07$ $\left(1 \mathrm{H}, \mathrm{d},{ }^{3} J_{\mathrm{HH}}=4.6 \mathrm{~Hz}, p\right.$-cym), $5.43\left(1 \mathrm{H}, \mathrm{d},{ }^{3} J_{\mathrm{HH}}=5.6 \mathrm{~Hz}, p\right.$-cym $), 5.56\left(1 \mathrm{H}, \mathrm{d},{ }^{3} J_{\mathrm{HH}}=6.1 \mathrm{~Hz}, p-\right.$ cym), $5.63\left(1 \mathrm{H}, \mathrm{d},{ }^{3} J_{\mathrm{HH}}=6.1 \mathrm{~Hz}, p\right.$-cym), $7.01\left(2 \mathrm{H}, \mathrm{d},{ }^{3} J_{\mathrm{HH}}=8.1 \mathrm{~Hz}\right.$, Arom $), 7.30-7.47(17 \mathrm{H}, \mathrm{m}$, Arom, $\left.\mathrm{PPh}_{3}\right)$. ES MS (m/z): $795.1573[M]^{+}, 533.0670\left[M-P P h_{3}\right]^{+}$. Anal. Calcd. for $\mathrm{C}_{41} \mathrm{H}_{48} \mathrm{~F}_{6} \mathrm{~N}_{2} \mathrm{OP}_{2} \mathrm{RuSe}$ (940.80): C, 52.34; H, 5.14; N, 2.98\%, Found: C, 52.24; H, 5.27; N, 3.13\%. 


\section{Acknowledgements}

We thank RETORTE GmbH for a generous gift of selenium metal and A.M. gratefully acknowledges a scholarship from the University of Wuppertal.

\section{References}

1. Douglass, I. B. J. Am. Chem. Soc. 1937, 59, 740.

2. Bulka, E.; Ahlers, K. D.; Tuček, E. Chem. Ber. 1967, 100, 1459.

3. Köhler, R.; Beyer, L.; Moll, M. Tetrahedron 1990, 46, 7735.

4. Zhou, Y.; Heimgartner, H. Helv. Chim. Acta 2000, 83, 539.

5. Petrov, M. L.; Zmitrovich, N. I. Russ. J. Gen. Chem. 1999, 69, 245.

6. Garud, D. R.; Koketsu, M.; Ishihara, H. Molecules 2007, 12, 504.

7. Schuster, M.; König, K. H. Fresenius Z. Anal. Chem. 1987, 327, 102.

8. Schuster, M.; König, K. H. Fresenius Z. Anal. Chem. 1988, 331, 383.

9. Shome, S. C.; Mazumdar, M.; Das, S. K. J. Ind. Chem. Soc. 1980, 57, 69.

10. Bruce, J. C.; Revaprasadu, N.; Koch, K. R. New J. Chem. 2007, 31, 1647.

11. Akhtar, J.; Bruce, J. C.; Malik, M. A.; Koch, K. R.; Afzaal, M.; O’Brien, P. Mater. Res. Soc. Symp. Proc. 2009, 1148E, 1148.

12. Fuge, F.; Lehmann, C.; Mohr, F. J. Organomet. Chem. 2009, 694, 2395.

13. Pisiewicz, S.; Rust, J.; Lehmann, C. W.; Mohr, F. Polyhedron 2010, 29, 1968.

14. Alagöz, C.; Brauer, D. J.; Mohr, F. J. Organomet. Chem. 2009, 694, 1283.

15. Kampf, M.; Richter, R.; Griebel, J.; Weller, A.; Kirmse, R. Z. Anorg. Allg. Chem. 2005, 631, 698.

16. Hartley, F. R. Organometal. Chem. Rev. A 1970, 6, 119.

17. Bennett, M. A.; Smith, A. K. J. Chem. Soc., Dalton Trans. 1974, 233. 